\title{
Rüzgâr Elektrik Santrallerinin Kontrolü İçin Kullanılabilecek Doğrulamalı Kod Kütüphanesi Geliştirilmesi
}

\author{
İzzet ALAGÖZ $^{1 \mathrm{a}^{*}}$ \\ ${ }^{1}$ Elektrik Üretim Anonim Şirketi Genel Müdürlüğü, Genel Müdürlük, Ankara/TÜRKIYYE \\ izzetalagoz@hotmail.com
}

Received/Geliş: 16.02.2021

Accepted/Kabul: 02.05.2021

Öz: Rüzgâr elektrik santrallerinde (RES) karşılaşılan önemli sorunlardan biri, kontrol sistemlerindeki standartlaşma eksikliğidir. Bu nedenle üretici ve işletmeciler ya dış kurumlara bağımlı kalmakta ya da rekabetçi olabilme ve fark yaratabilme adına kendi yazılımlarını geliştirmektedir. Mevcut soruna çözüm olarak bu çalı̧̧mada, herhangi bir rüzgâr elektrik santralinin kontrolünde kullanılabilecek, pratik uygulamaları olan doğrulamalı kod kütüphanesi geliştirilmesi hedeflenmiş ve bu sayede markaya bağımlılığın en aza indirilmesi öncelenmiştir. Çalışmada geliştirilen IZARES adlı sistem, Uluslararası Elektroteknik Komisyonu (IEC) standartları ile uyumlu olup rüzgâr enerjisi, kontrol sistemleri ve standardizasyon alanlarında yapılan çalı̧̧maların bir kesişim noktası durumundadır. Bundan sonraki çalışmalara öncü olabilecek ve sonradan herhangi bir türbin üreticisinin sisteme sorunsuz intibakına olanak tanıyacak olan bu doğrulamalı kod kütüphanesi sayesinde açık bir sistem elde edilerek standartlaşma yönünde bir katkı sağlanmaya çalışılmıştır.

Anahtar Kelimeler: Rüzgâr türbinleri, kontrol sistemleri, standartlaştırma, doğrulama, güç faktörü.

\section{Developing Validated Code Library for Controlling Wind Power Plants}

\begin{abstract}
One of the major problems encountered in wind power plants (WPP) is the lack of standardization in the control systems. Therefore, manufacturers and operators either remain dependent on external institutions or develop their own software in order to be competitive and make a difference. As a solution to the current problem, in this study, it was aimed to develop a verified code library with practical applications that can be used in the control of any wind power plant, thus minimizing brand dependency. The system named IZARES developed in the study complies with the International Electrotechnical Commission (IEC) standards and is an intersection point of studies in the fields of wind energy, control systems and standardization. This library of validated code, which can be a pioneer in the next studies, and which will allow any turbine manufacturer to adapt to the system without any problems, has been used to obtain an open system and contribute towards standardization.
\end{abstract}

Keywords: Wind turbines, control systems, standardization, validation, power factor.

\section{Giriş}

Dünyanın birincil enerji kaynakları hızla tükenmekte olup var olan fosil yakıtların elde edilme maliyetleri de gün geçtikçe artmaktadır. Birincil enerji kaynaklarını çeşitlendirme veya dışa bağımlılıklarını en aza indirgeme odaklı enerji politikalarına sahip ülkeler gibi Türkiye'de de yenilenebilir enerji kaynaklarına eğilim artış göstermektedir. Rüzgâr teknolojileri de bunların arasında önemli bir yere sahiptir. Bunun sonucu olarak da rüzgâr elektrik santrali kontrol sistemlerinde standartlaşmanın önemi her geçen gün artmaktadır. Üretici ve yatırımcılar yazılım konusunda dışa bağımlılıklarının önüne geçebilme ve rekabet unsurunu işletebilme adına kendi

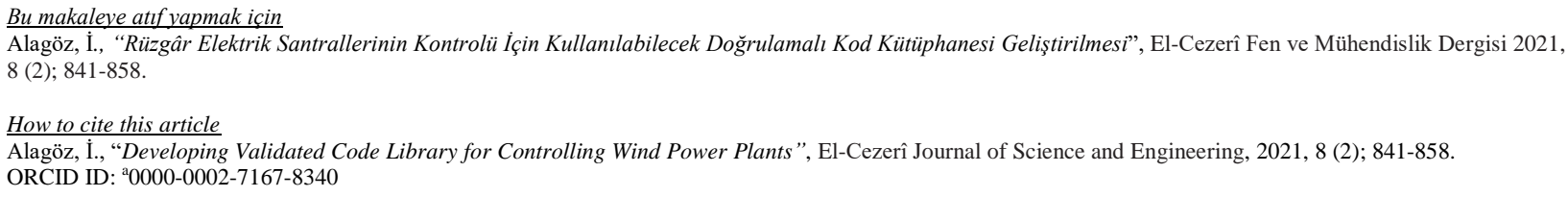


yazılımlarını geliştirmektedir. Ancak bu yazılımlar birbirleri arasında kesin farklılıklar ortaya koyduğundan, bir kontrol sistemi için yazılan bir program diğer kontrol siteminde uygulanamamakta ve bu durum da standardizasyona ulaşmanın önünde önemli bir engel teşkil etmektedir.

Bu çalışmada, açık bir sistem geliştirilmiş olup üç ana soruna katkı sağlanması hedeflenmiştir [1];

- Yatırımcıların dışa bağımlılıklarının sadece türbin kalemine indirgenerek satın alma sonrası bu bağımlılığın ciddi oranlarda azaltılması.

- Türbin üreticilerini yazılım konusunda özgürlüğüne kavuşturarak otomasyon firmalarına olan bağımlılıklarının azaltılması.

- Geliştirilen kod kütüphanesinin standart bir uygulamaya doğru gitmesi durumunda, bir santralde tecrübe edinen personelin başka santrallerde de benzer hizmetleri yürütebilmesine kolaylık sağlanması.

Çalışmada, daha yaygın olan küçük ve orta ölçekli (1000 kW ve daha küçük) rüzgâr türbinleri hedef seçilmiştir. Bu türbinlerin yatırım maliyetlerinin düşük olması, kontrol sistemi bütçelerinin de dar olması anlamına geleceğinden, ihtiyacın daha çok hissedildiği bir noktada çözüm üretmenin daha hedef odaklı olacağı düşünülmüştür. Ayrıca bu çalışmada, daha kararlı ve güvenilir bir kontrol imkânı sunan aktif kontrol sistemi tercih edilerek, şebekeye bağlı ve üretilen enerjiyi direkt çıkışa veren doğrudan uyartımlı sistemler temel alınmıştır. Donanım seçiminde yapılan tercihlerde ise geliştirilen sistemin mümkün olabildiğince farklı marka ve model ile uyumlu olması amaçlanarak, rüzgâr elektrik santrallerinin kontrol sistemlerinde standartlaşma çalışmalarına, özgün ve öncül bir çalışma olarak literatüre katkı sağlanmaya çalışılmıştır.

\section{Rüzgâr ve Rüzgâr Türbinleri}

Dünyadaki enerjiye olan ihtiyaç ve talepler, diğer enerji gruplarını elektrik enerjisine dönüştürme yönünde zorunlu kılmaktadır. Birincil enerji kaynaklarının sınırlı oluşu ve çevreye verdiği zararlar dikkate alındığında, temiz ve yenilenebilir enerji kaynaklarının önemi karşımıza çıkmaktadır.

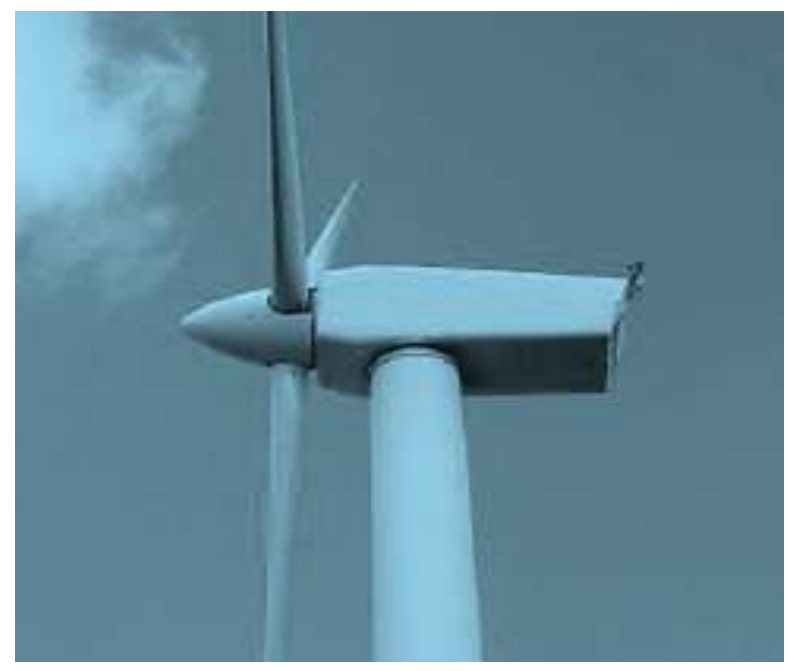

Şekil 1. Yatay eksenli, önden rüzgârlı, üç kanatlı, durdurmalı ve değişken hızlı rüzgâr türbini

Yenilenebilir enerji kaynaklarının en önemlilerinden birisi olan rüzgâr; kutuplar ile tropik alanlar arasındaki 1sı farkından kaynaklanan küresel 1sı transferidir. Rüzgârın ana kaynağı güneştir ve güneş var oldukça rüzgârda var olacaktır. Rüzgâr bu şekilde sürekli var olacağından kaynak tüketilmesi de söz konusu olmayacaktır. Lakin değerlendirilmediği sürece varlığı sadece bir doğa 
olayı olarak kalacaktır [2]. Rüzgâr türbinleri, rüzgârın sahip olduğu kinetik enerjiyi elektrik enerjisine dönüştüren sistemlerdir. Rüzgâr türbinleri üzerine ek bir yük getirmemesi ve kanatların tüm rüzgâr hızlarında neredeyse sabit atalet momentine sahip olması sebeplerinden ötürü türbinlerde en çok rastlanan kanat sayısı üçtür [3]. Bu çalışmada da Şekil 1'de görülen; yatay eksenli, önden rüzgârlı, üç kanatlı, durdurmalı ve değişken hızlı türbinler temel alınmıştır [4]. Temel alınan bu rüzgâr türbininin mekaniksel ve elektriksel parçaları ise Şekil 2'de görülmektedir [5].

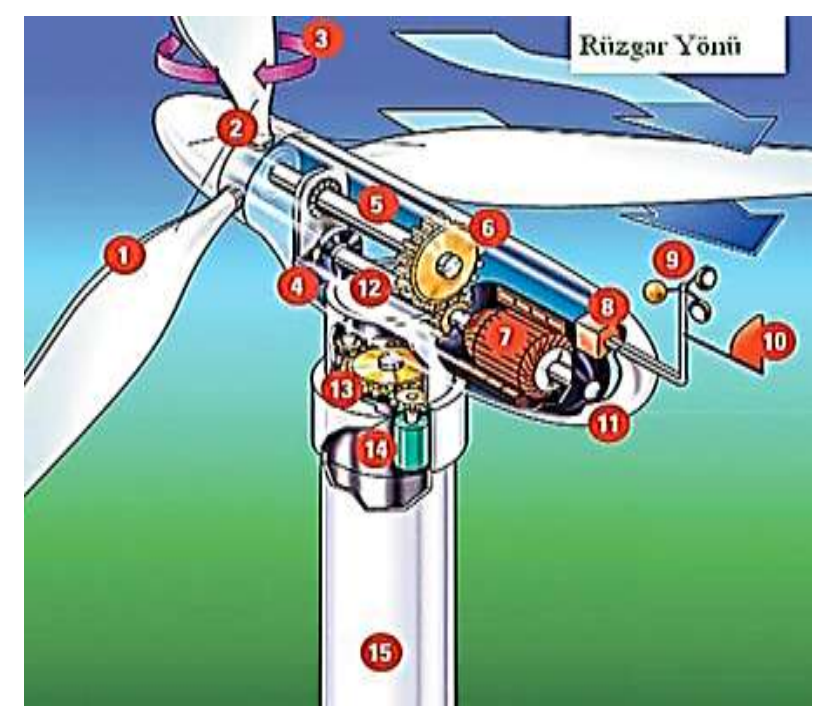

Şekil 2. Rüzgâr türbini ana öğeleri

Şekil 2'de numaralarla ifade edilen türbin parçaları;
1. Kanatlar
6. Hız ayarlama dişlileri
11. Nacelle
2. Rotor
7. Jeneratör
3. Pitch
8. Kontrolör
12. Yüksek hız mili
4. Fren
9. Anemometre
13. Yön sürücü
5. Düşük hız mili
10. Yönlendirici
14. Yön motoru
15. Kule

\subsection{Rüzgâr Gücü}

Rüzgâr türbinleri ile ilgili ilk teorik çalışma, Göttingen Üniversitesinde Albert Betz tarafından yapılmıştır. Betz; rüzgâr türbinlerini, göbeksiz ve sonsuz kanatlı olduğunu veya diğer bir ifadeyle ideal olduğunu varsayarak hesaplarını yapmıştır. Betz'in teorisine göre, rüzgâr türbinlerinin güç ve performans hesapları aşağıdaki gibi açıklanmaktadır [6].

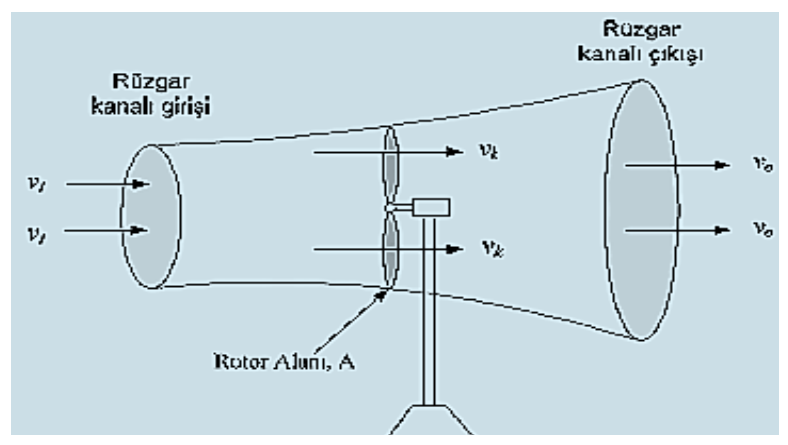

Şekil 3. Rüzgâr kanalı boyunca oluşan rüzgâr hızları 
Rüzgâr türbinlerinde kanatlar tarafından yakalanan maximum güç; Şekil 3’te görüldügü gibi, rüzgâr kanalı girişi ile çıkışı arasındaki kinetik enerjinin farkıdır (Eş.1) [7].

$$
\mathrm{P}_{\max }=1 / 2 \mathrm{~m}\left(\mathrm{v}_{\mathrm{i}}^{2}-\mathrm{v}_{0}^{2}\right)
$$

$\mathrm{P}_{\max } \quad$ : Rüzgârdan elde edilebilecek maksimum güç (W)

$\mathrm{m}$ : Birim zamanda akan hava kütle miktarı $(\mathrm{kg} / \mathrm{s})$

$\mathrm{v}_{\mathrm{i}} \quad$ : Kanat girişlerindeki rüzgâr hızı $(\mathrm{m} / \mathrm{s})$

$v_{0} \quad$ : Kanat çıkışlarındaki rüzgâr hızı $(\mathrm{m} / \mathrm{s})$

Birim zamanda akan hava kütle miktarı ise havanın yoğunluğu, kanatların süpürme alanı ve kanat düzlemindeki rüzgâr hızı ile orantılıdır (Eş.2).

$$
\mathrm{m}=\rho \mathrm{S} \mathrm{v}_{\mathrm{k}}
$$

$\rho \quad$ : Hava yoğunluğu $\left(\mathrm{kg} / \mathrm{m}^{3}\right)$

$\mathrm{S} \quad$ : Kanatların süpürme alanı $\left(\mathrm{m}^{2}\right)$

$\mathrm{v}_{\mathrm{k}} \quad$ : Kanat düzlemindeki rüzgâr hızı $(\mathrm{m} / \mathrm{s})$

Kanat düzlemindeki rüzgâr hızının değeri, kanat girişi ile kanat çıkışındaki rüzgâr hızının ortalamasıdır (Eş.3).

$$
\mathrm{v}_{\mathrm{k}}=1 / 2\left(\mathrm{v}_{\mathrm{i}}+\mathrm{v}_{0}\right)
$$

Eş.2 ve Eş.3'ü, Eş.1'de yerine konulduğunda Eş.4 elde edilir;

$$
P_{\max }=1 / 2 \rho S 1 / 2\left(v_{i}+v_{0}\right)\left(v_{i}^{2}-v_{0}^{2}\right)
$$

Eş.4 düzenlendiğinde ise Eş.5'e ulaş1lır;

$$
\mathrm{P}_{\max }=1 / 2 \rho \mathrm{S} \mathrm{v}_{\mathrm{i}}^{3}\left[1 / 2\left(1+\mathrm{v}_{0} / \mathrm{v}_{\mathrm{i}}\right)\left(1-\mathrm{v}_{0}^{2} / \mathrm{v}_{\mathrm{i}}^{2}\right)\right]
$$

Eş.5'ten elde edilen Eş.6'da; rüzgârdan elde edilen maximum gücün, kanat girişlerindeki rüzgâr hızının küpü ile orantılı olduğu görülmektedir.

$$
\begin{gathered}
\mathrm{P}_{\max }=1 / 2 \rho \mathrm{S} \mathrm{v}_{\mathrm{i}}^{3} \mathrm{c}_{\mathrm{p}} \\
\mathrm{c}_{\mathrm{p}}=1 / 2\left(1+\mathrm{v}_{0} / \mathrm{v}_{\mathrm{i}}\right)\left(1-\mathrm{v}_{0}^{2} / \mathrm{v}_{\mathrm{i}}^{2}\right)
\end{gathered}
$$

Eş.7'de yer alan $c_{p}$ ise türbin güç faktörü olup rüzgârdan elde edilebilecek maksimum gücü belirten kavramdır. Eş. 7' deki ifadenin türevi alınıp sıfıra eşitlendiğinde ise $\mathrm{v}_{0} / \mathrm{v}_{\mathrm{i}}=1 / 3$ değerinde güç faktörü maksimum 16/27 değerini alacaktır. Buna Betz Limiti adı verilir. Bu demektir ki, rüzgârdan elde edilebilecek maksimum güç, toplam rüzgâr gücünün 16/27'sidir. c $c_{p}$ değeri iki kanatlı türbinler için yüksek hızlarda 0.5 'in altındadır ve daha fazla kanatlı rüzgâr türbinlerinde düşük hızlarda 0.2 ile 0.4 arasında değişmektedir. Pratik olarak maksimum rotor verimi 0.5 olarak alınırsa birim süpürme alanı için rüzgâr türbininin maksimum güç çıktısı Eş.8' deki gibi basit bir ifade ile tanımlanabilir [8].

$$
\mathrm{P}_{\max }=1 / 4 \rho \mathrm{v}_{\mathrm{i}}^{3}
$$

Şekil 4'de ise bir rüzgâr türbininin, rüzgâr hızını rüzgâr gücüne çevirme oranının istatiksel sonuçları görülmektedir [9]. 


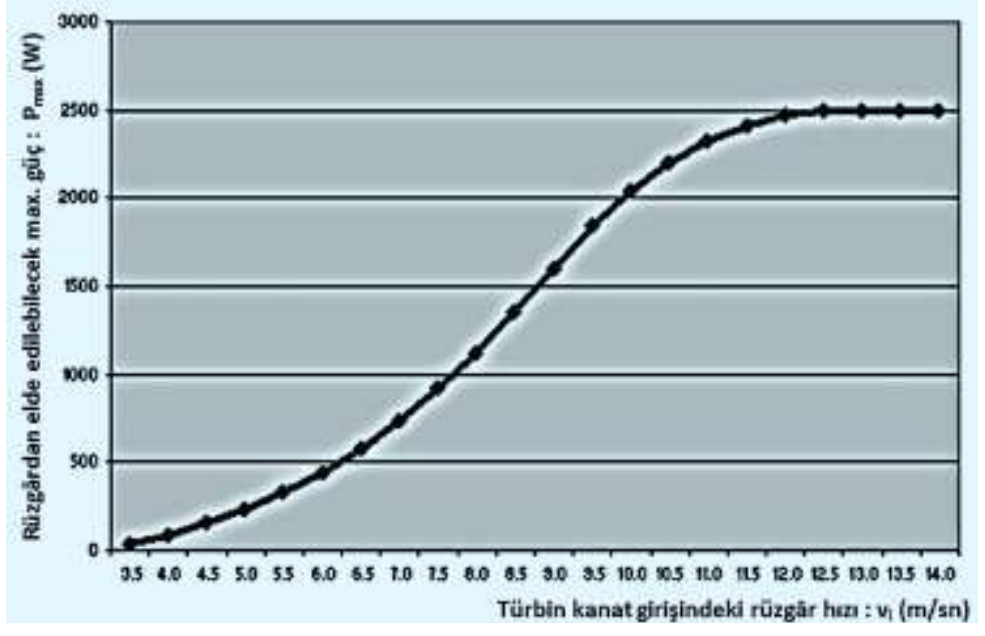

Şekil 4. Rüzgâr türbininde güç-rüzgâr hızı eğrisi

Türbin $4 \mathrm{~m} / \mathrm{s}$ rüzgâr hızında devreye alınır, $14 \mathrm{~m} / \mathrm{s}$ rüzgâr hızına kadar çıkış gücü çizgisel olarak artar ve $25 \mathrm{~m} / \mathrm{s}$ rüzgâr hızına kadar çıkış gücü sabit kalır. $25 \mathrm{~m} / \mathrm{s}$ rüzgâr hızı aşıldığında ise türbin devre dışı olur. Kanatların boyları, tasarım sonrası sabit olduğu için rüzgâr gücüne katkısı da sabittir.

\section{Rüzgâr Türbini Kontrol Sistemleri}

Türbin dünyasının önemli isimlerinden olan Enercon Firması ürettiği rüzgâr türbinlerinde, Moeller marka XC-100-FC modüler programlanabilen mantık denetleyiciyi kullanılacağını beyan etmiştir [10]. Yine yazılım sektörünün öncülerinden olan National Instruments Firması tarafından yayınlanan bir çalışmada ise rüzgâr türbin kontrol metotları ile olası rüzgâr değerlerine karşı uygulanacak kontrol stratejileri ortaya koyularak ana kontrol parametreleri belirlenmiş lakin bu parametrelerin programlama işi dış kurumlara bırakılmıştır [11]. Bu örnekler, bu çalışmada belirtildiği gibi üretici firmaların dışa bağımlılıklarının önemli birer delili niteliğindedir. Hem üretici hem de yatırımcı tarafında yaşanan bu dışa bağımlılık neticesinde, rüzgâr türbini kontrol sistemlerinde standardizasyona gidilmesinin kaçınılmaz bir ihtiyaç olarak sektörün karşısına çıtığı görülmektedir.

\subsection{Standartlar}

Uluslararası Elektroteknik Komisyonu, programlanabilir mantık denetleyicilerin programlama dilleri için IEC 61131 standardını tanımlamıştır. Bu standart, elektronik otomasyon kontrol sistemlerinde yazılım belirleme noktasında temel olarak birtakım prensipler ve tasarım spesifikasyonları tanımlayarak her marka ve model için farklılıkları ortadan kaldırmaya katkı sağlamıştır [12]. Rüzgâr elektrik santrallerinin kontrol sistemleri için ise kabul görmüş uluslararası bir standart yoktur [13]. Rüzgâr elektrik santralleri kontrol sistemlerinde standartlaşma adına bu çalışmada geliştirilen sistem aynı zamanda IEC 61131 standardı ile de uyumludur. Ayrıca çalışmada doğrulama denetimleri, IEC 61131 standardı ile de örtüşen, GAMP (İyi Otomasyon Üretim Pratikleri) standartları kapsamında yapılmıştır [14].

\subsection{Rüzgâr Türbini Kontrol Sistemi Opsiyonları}

Rüzgâr elektrik santralleri projeleri için, fiyat ve performans karakteristikleri göz önüne alınarak ihtiyacı karşılayabilecek hatta yakın zamanda gerçekleşebilme ihtimali olan genişlemelere de imkan tanıyacak şekilde aşağıdaki kontrol sistemlerinden optimum özellikte olanı seçilmelidir. 
- Röleli kontrol sistemleri

- Mikroişlemcili kontrol sistemleri

- Programlanabilir mantık denetleyicili (PLC) kontrol sistemleri

- Dağıtılmış kontrol sistemleri (DCS)

Röleli kontrol sistemleri en eski yöntem olup kontrol yeteneği düşüktür ve yeterli bir çözüm değildir. Mikroişlemcili sistemler ise tek başlarına kontrol sistemlerine müdahale edemeyeceklerinden özel donanımlarla desteklenmesi gerekmektedir [15]. Dağıtılmış kontrol sistemleri, genel olarak yüksek yoğunluktaki endüstriyel tesislere entegre edilmiş bilişim ağı kontrol mimarisi olup pahalı ve lüks bir çözümdür [16]. Programlanabilir mantık denetleyiciler ise son kullanıcılara uygulama desteği veren ve üretim performansının geliştirilmesine yardımcı olan kontrolörlerdir [17]. Bilgisayarlarla ve diğer kontrolörlerle haberleşme imkânı tanıması ve orta ölçekli bir elektrik santrali için ideal sayıda giriş/çıkış kontrolüne olanak sağlaması da avantajları arasındadır [18]. Bu çalışmada da programlanabilir mantık denetleyicili kontrol sisteminin kullanılması optimum çözüm olarak görülmüştür.

\subsection{Rüzgâr Türbini Kontrol Sistemi Birimleri}

Kontrol sisteminin amacı parametreleri kontrol ederek türbin faaliyetlerini bütün iklim ve rüzgâr koşullarında en verimli enerji üretecek şekilde optimize etmektir. Sistemde kontrol edilecek tüm parametrelerin, ana işlem birimine bağlı olan diğer kontrol sistem birimlerine dağıtılması kontrol işini kolaylaştıracaktır. Her birim ne kadar mükemmel olursa olsun, rüzgâr enerjisinden en verimli şekilde elektrik enerjisinin üretilmesi, Şekil 5'de görüldügü gibi tüm kontrol sistem birimlerinin, ana işlem birimine bağlı olarak uyum içinde çalışmalarına bağlıdır [19]. Bu uyumun en sorunsuz şekilde gerçekleştirilmesi ve bunun belli bir standarda oturtulması da çalışmanın hedefini teşkil etmektedir.

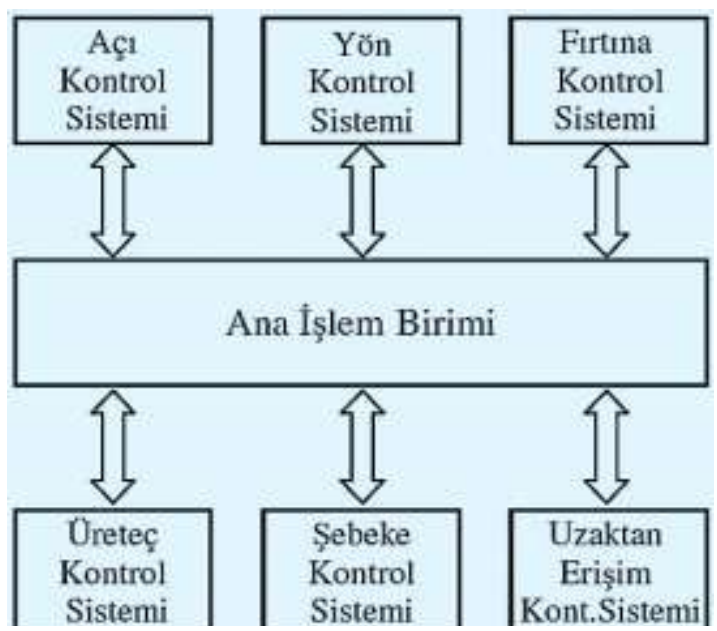

Şekil 5. Rüzgâr türbini kontrol sistemi birimleri

\section{Yöntem}

Bu çalışmada işlemler, üç ana başlık altında yapılmıştır.

\subsection{Kod Kütüphanesinin Oluşturulması}

Kod kütüphanesinin oluşturulması için aşağıdaki akış diyagramında verilen işlem adımları izlenmiştir (Şekil 6). 


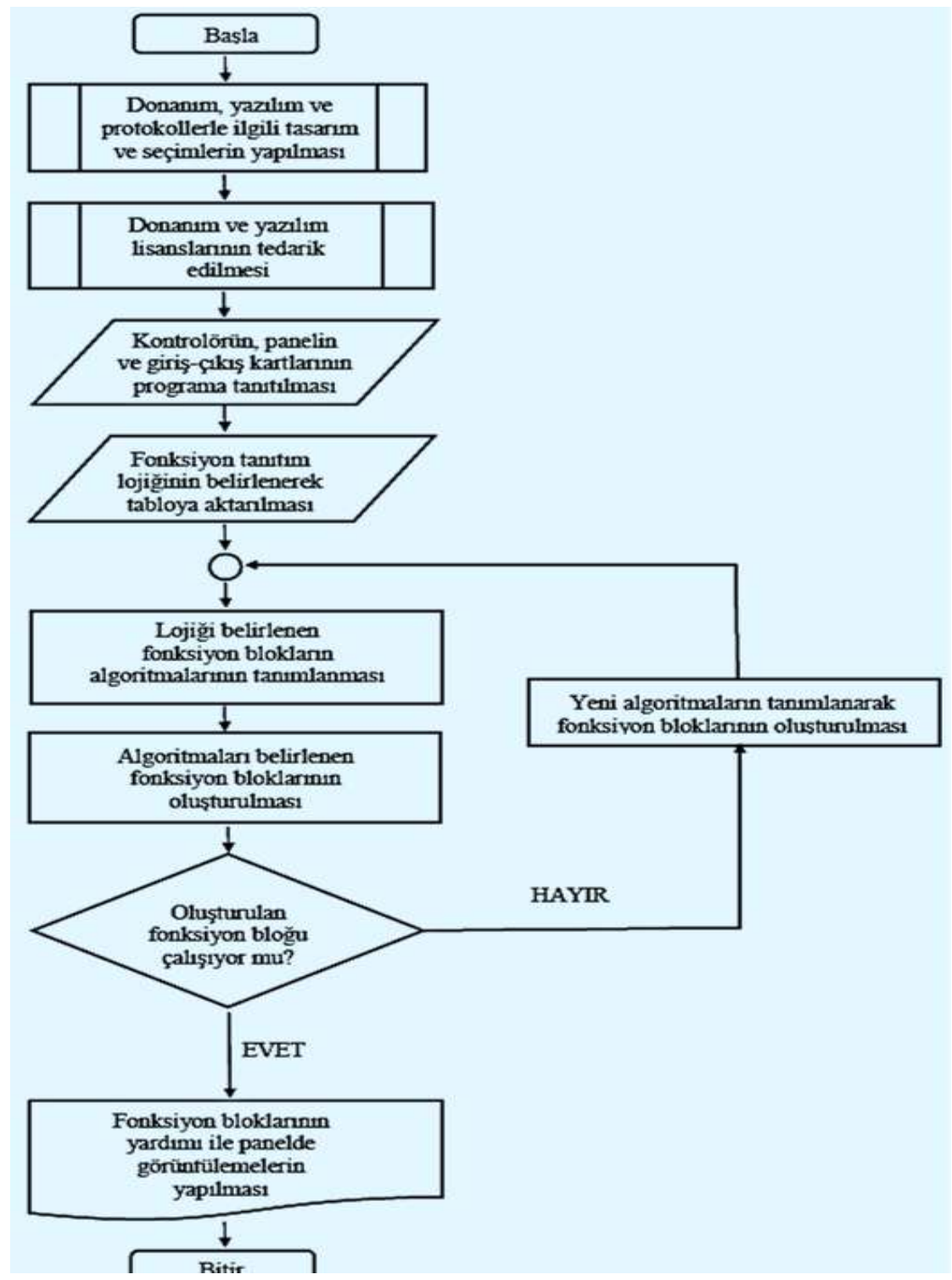

Şekil 6. Kod kütüphanesinin oluşturulması akış diyagramı

\subsection{Doğrulama (Validasyon)}

Çalışmada, standartlaşmadaki güvenilirliğin arttırılması, objektif sonuçların elde edilmesi ve tarafsız bir kullanıcının gözüyle değerlendirmenin yapılması ile çalışmaya pozitif katkılar sağlanması açısından, doğrulama uygulamasının kullanılması uygun görülmüştür. Doğrulama denetimi için birinci seviye testler, program testleri kapsamında yapılmıştır. İkinci seviye testler için birinci denetim, rastgele fonksiyonlar seçilerek Ege Üniversitesi Mühendislik Fakültesi ElektrikElektronik Bölümü tarafından, ikinci denetim ise sektör içerisinde faaliyet gösteren Christ-Goema $\mathrm{GmbH}$ tarafından yapılmış ve onaylanmıştır (Şekil 7). 


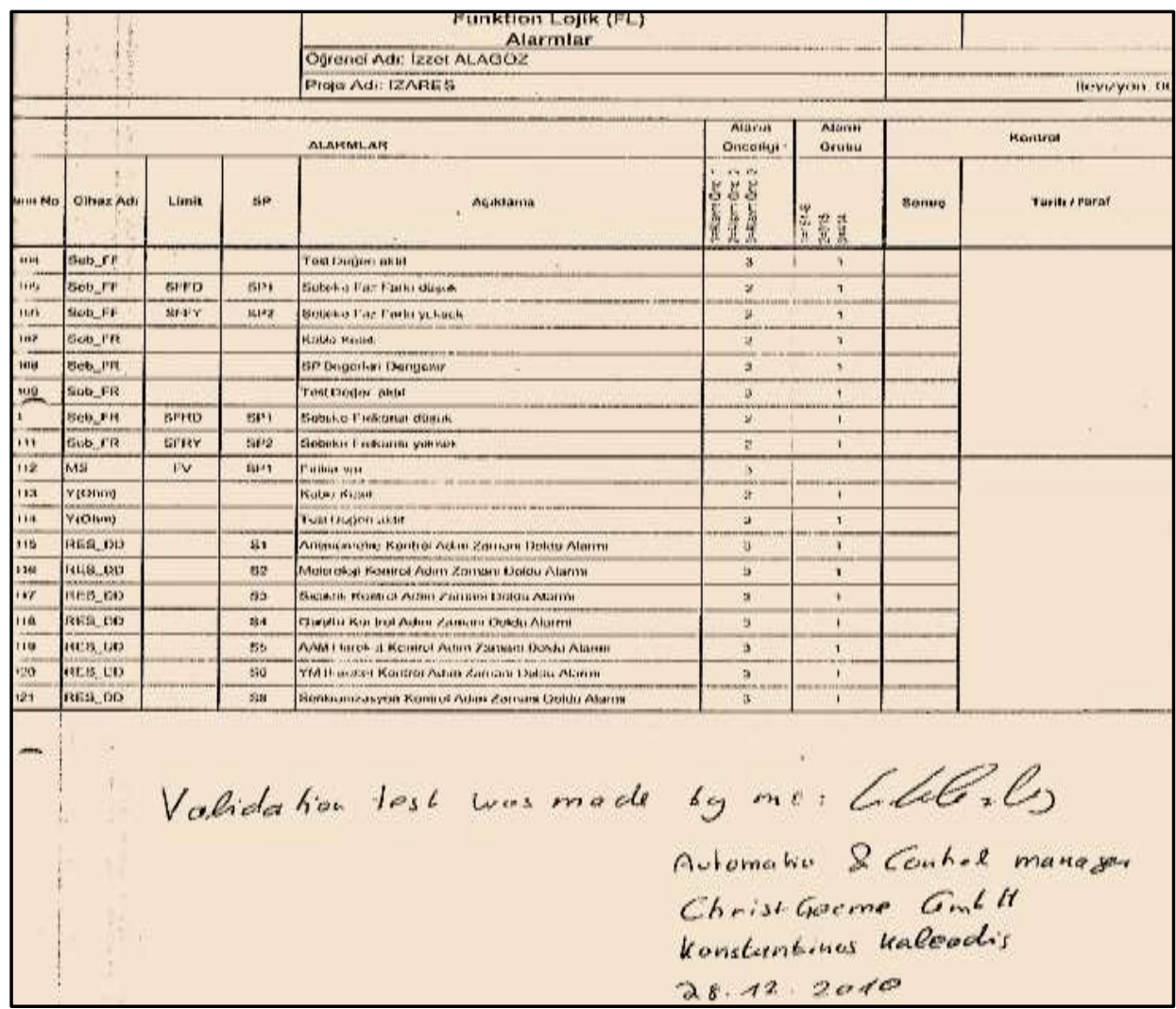

Şekil 7. Christ-Goema GmbH doğrulama denetimi

\subsection{Test ve Uygulama}

Programın çalışabilirliğinin ortaya konulması, aşağıdaki eylem basamakları ile gerçekleştirilmiştir;

- Programın çalıştırılarak gerekli testlerin tamamlanması

- Tamamlanmış programın simülasyonunun yapılması

- Bir santralde çalışıyormuşçasına gerçek işlemci ve panel üzerinde uygulama gerçekleştirilmesi

\section{Uygulama}

$\mathrm{Bu}$ çalışma ile geliştirilen sisteme IZARES adı verilmiştir. Sistemde, IEC 61131 standardı gereği öncelikle donanım konfigürasyonunun, daha sonra da yazılım konfigürasyonunun hazırlanması öngörülmüştür.

\subsection{Donanım Konfigürasyonu}

Programlanabilir mantık denetleyicisi üreticileri, bir otomasyonun tüm kontrol sistemini tek çözüm altında toplayamayacaklarından diğer kontrol sistemleri ile uyumlu çalışabilecek arayüz modülleri üretmişlerdir [20]. Bu çalışmada da geliştirilen sistemin birçok marka ve modelle uyumlu çalışabilmesi için arayüz modüller tercih edilmiştir. Şekil 8. (a)'da görüldügüü gibi, ekonomik ve entegrasyon avantajları yanında, tek başına da çalışabilecek şekilde tasarlanan ve santral modellerinin de değişebilme ihtimaline karşın, 1024 giriş/çıkış kapasiteli bir arayüz modülü olan Siemens $\quad$ IM 151-8 işlemcisi kontrolör olarak seçilmiştir. İşlemcinin diğer merkezi işlem birimleri ile programlanabilirliği ve çalışabilirliğinin ortaya konulması açısından, işlemciyi programlayabilmek için Şekil 8. (b)'de görülen, Siemens S7-400 tabanlı CPU 414-3 ve Siemens S7300 tabanlı CPU 315-2DP programlama panelleri kullanılmıştır. Giriş/çıkış miktarları dikkate alınarak seçilen ve programlanan diğer donanım elemanları ise Tablo 1'de verilmiştir. 


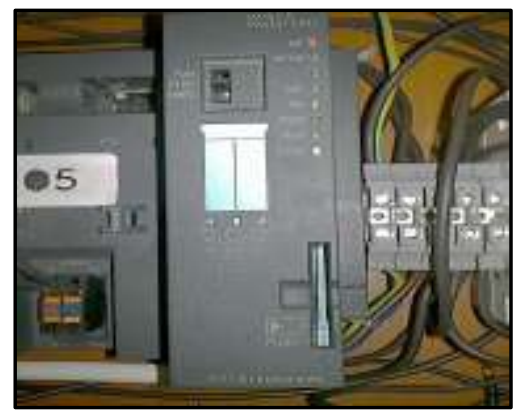

(a)

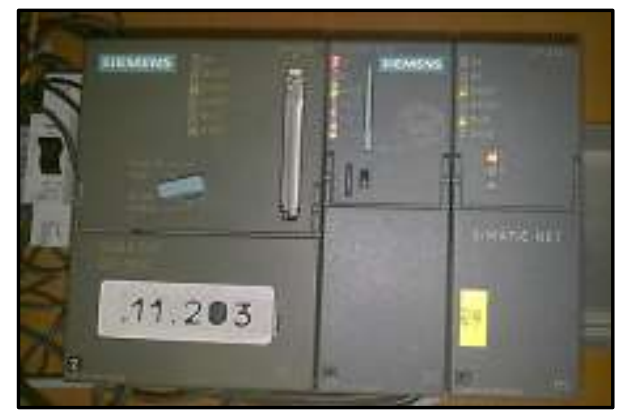

(b)

Şekil 8. a) Siemens IM 151-8 ana işlemci; b) Siemens S7-300 işlemci ailesi

Tablo 1. Donanım Listesi

\begin{tabular}{|c|c|c|c|c|c|}
\hline Sira & & Donanım Cinsi & Miktar & Kanal / Model & Ürün Kodu \\
\hline 1 & $\overline{\mathrm{CPU}}$ & (Merkezi İşlem Birimi) & 1 & IM 151-8 & 6ES7 151 - 8AB01 - 0AB0 \\
\hline 2 & DI & (Dijital Giriş Kartı) & 44 & 4 & 6ES7 131 - 4BD01 - 0AA0 \\
\hline 3 & DO & (Dijital Çıkış Kartı) & 18 & 2 & 6ES7 $132-4 \mathrm{HB} 01-0 \mathrm{AB} 0$ \\
\hline 4 & AI & (Analog Giriş Kartı) & 11 & 2 & 6ES7 $134-4 \mathrm{MB} 00-0 \mathrm{AB} 0$ \\
\hline 5 & $\mathrm{AO}$ & (Analog Çıkıș Kartı) & 4 & 2 & 6ES7 $135-4 \mathrm{~GB} 01-0 \mathrm{AB} 0$ \\
\hline
\end{tabular}

Donanımın liste halinde programa tanıtılması yanında, donanıma merkezi işlem birimi üzerinden ulaşabilmek için gerekli adresleme ve listeleme ise Simatic Manager yazılım tabanında, donanım yapılandırması içerisinde yapılmıştır (Şekil 9).

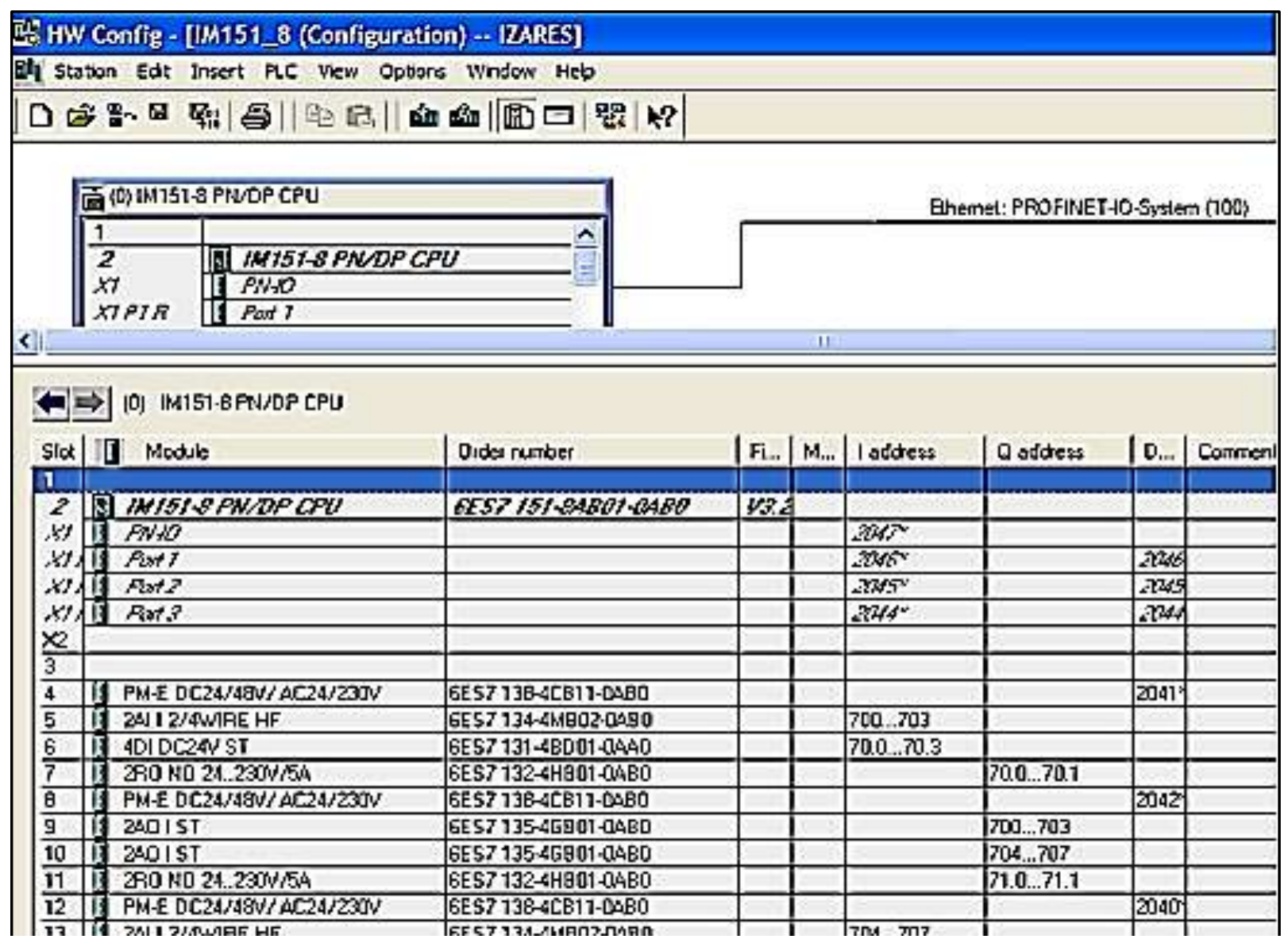

Şekil 9. Simatic Manager'da donanım konfigürasyonu 


\subsection{1. İnsan Makine Arayüzü}

$\mathrm{Bu}$ çalışmada, arayüz modülü olarak programlanabilir mantık denetleyicisi seçildiğinden, insan makine arayüzü olarak ta otomasyon dünyasında yaygın olarak kullanılan SCADA (Supervisory Control and Data Acquisition) tercih edilmiştir. SCADA, kurulu bir santrali ekranlar aracılığı ile takip ve kontrol imkânı sağladığı gibi santrallerin çalıştırılmadığı durumlarda da bir simülasyonel eğitim aracı olarak kullanılmasına olanak verir [21]. Çalışmada SCADA olarak seçilen kontrolör ile uyumlu tasarlanmış Siemens otomasyon grubunda kontrol yönetimi ve veri toplama çözümlerinden birisi olarak kullanılan ve kıyasla daha küçük sistemler için önerilen esnek uygulamalar ile haberleşme imkânlarına sahip Siemens WinCC Flexible 7.0 kullanılmıştır.

\subsubsection{Haberleşme Modeli ve Protokolü}

$\mathrm{Bu}$ çalışmada, tüm protokollerle haberleşebildiği için daha geniş bir yelpazeye hizmet verebilen, diğer kontrol sistemleri tarafından da tanınıp algılanabilen, dijital giriş/çıkış sınırlaması bulunmayan ve analog giriş/çıkış için işlemcilerle uyum problemi yaşamayan, akım ölçme temelli (4-20 mA) haberleşme standardı seçilmiştir. Ayrıca, özgün nitelikleri olan haberleşme protokolleri marka bağımlılığını beraberinde getirdiğinden, genişleyebilme ve farklı türbin markalarına hitap edebilme özelliklerinden dolayı da protokol temeli olarak, ethernet bağlantı modeli ve TCP/IP haberleşme protokolü seçilmiştir [22].

\subsection{Yazılım Konfigürasyonu}

Çalışmada, seçilen işlemciler Simatic Manager yazılım tabanında programlanmış ve donanım elamanları tanımlanmıştır (Şekil 10).

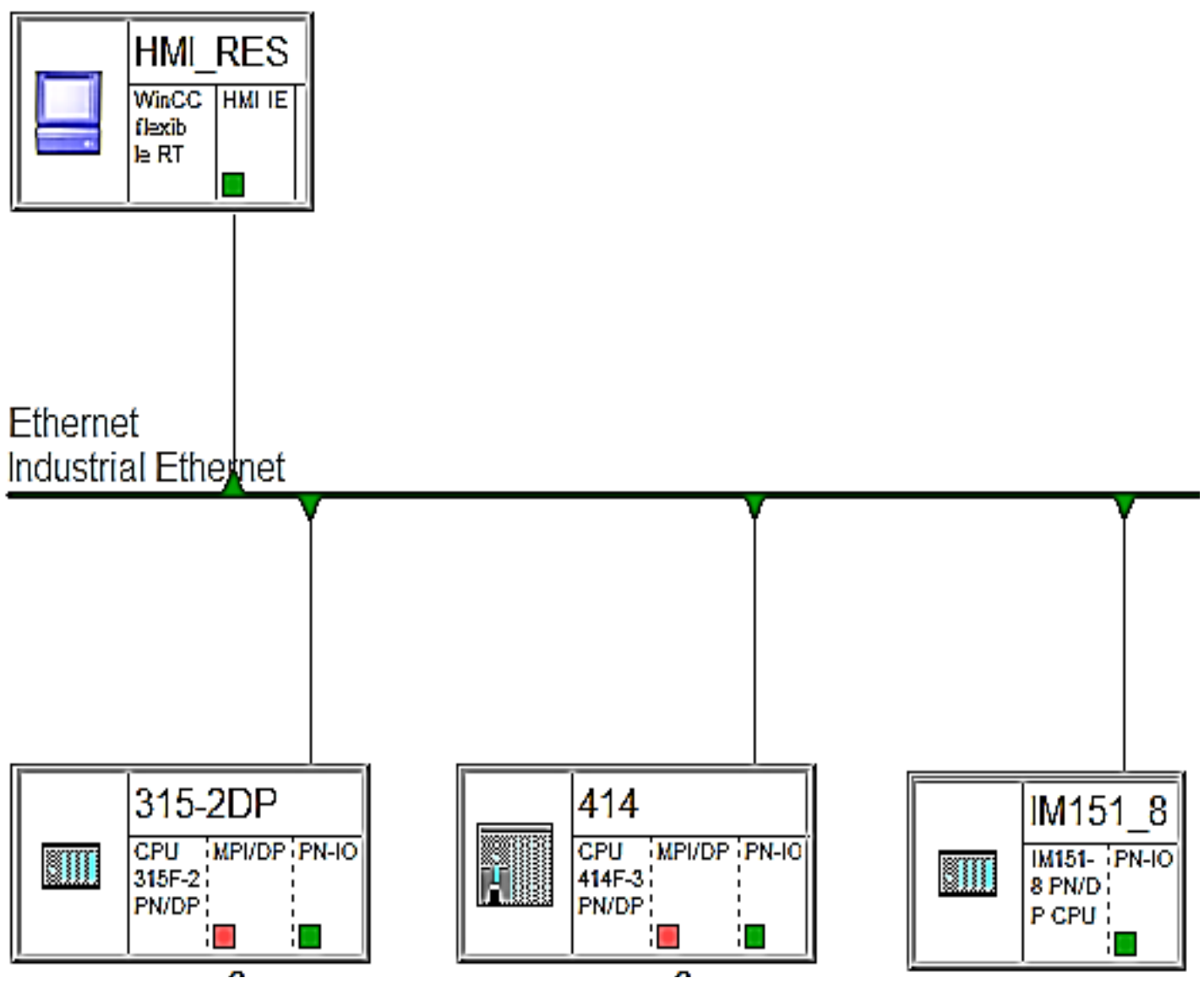

Şekil 10. İşlemcilerin tanımlanması 


\subsubsection{Organizasyon Blokları}

$\mathrm{Bu}$ çalışmada, geliştirilen sistemin Simatic Manager'da nasıl çalışacağı organizasyon blokları ile belirlenmiştir (Şekil 11). Organizasyon blokları otomatik olarak oluşmakta ve pek fazla müdahale imkânı olmamaktadır. Programın çalışma motoru olduğu için yazılacak program satırları, organizasyon bloklarının öngördüğü şekilde çalışacaktır.

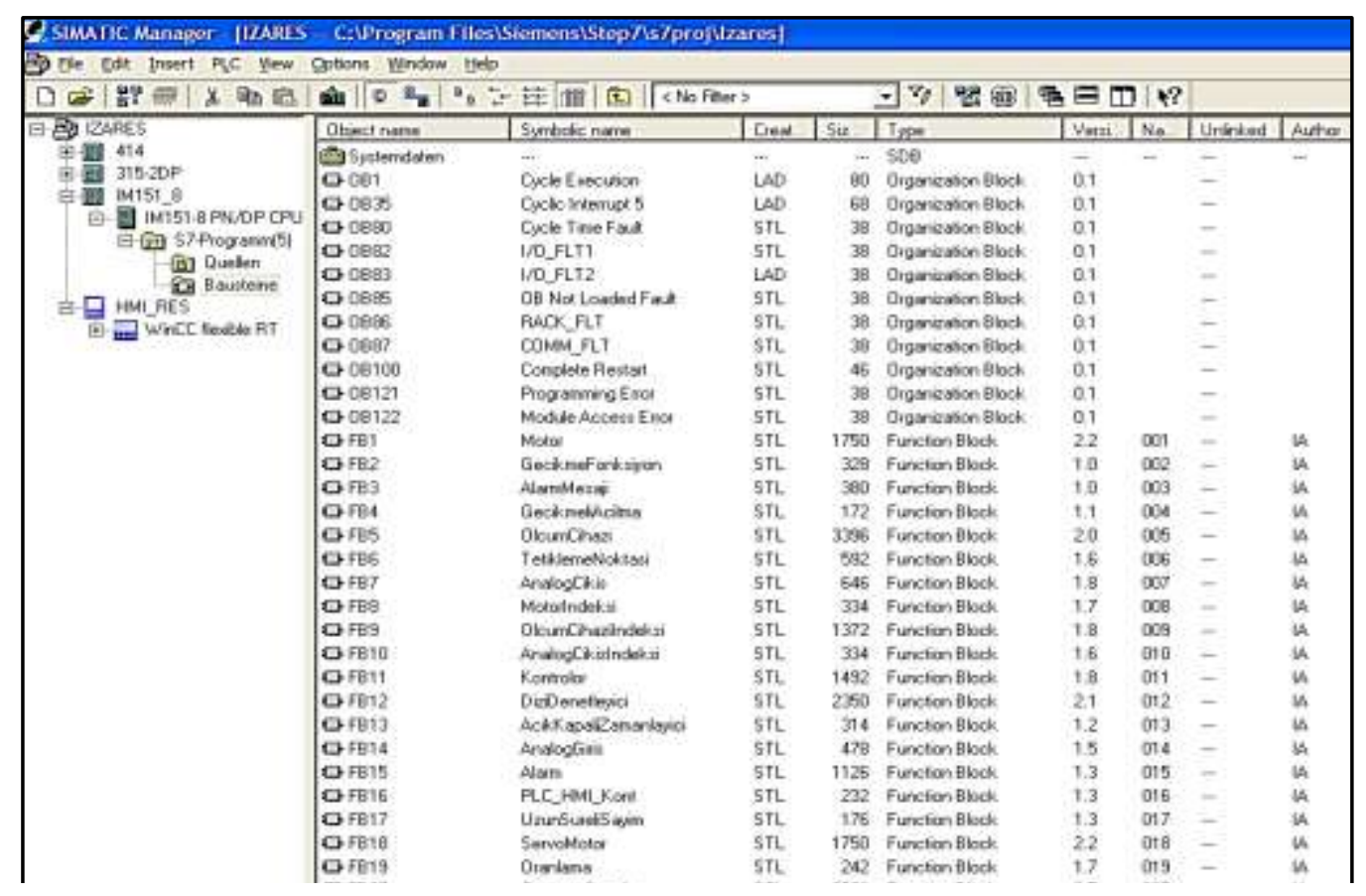

Şekil 11. Simatic Manager'da organizasyon blokları

\subsubsection{Fonksiyon Lojik Tabloları}

Çalışmada, kontrol programındaki tüm parçacıkların, mikro düzeyde bölünerek, tek başına çalışabilen her bir parçasının özgün ismiyle kaydedilip testlerinin yapıldıktan sonra bir kod kütüphanesi içerisinde sunulması standartlaşma açısından gerekli görülmüştür. Geliştirilen sistemin tüm öğeleri öncelikle bu şekilde tanımlanmış ve daha sonra programlamaya geçilmiştir. Ayrıca, bir rüzgâr elektrik santralinde kullanılacak fonksiyon lojik tanımları çıkartılarak tablo aracılığı ile detaylandırılmış ve fonksiyon tanım kütüphanesi oluşturulmuştur. Eklenmesi gereken herhangi bir yeni fonksiyonun, oluşturulan kütüphanede tanımlanması ile başlayacak aşamalar, mevcut format ve prensipler kullanıldığı takdirde, işlemler bilindik silsile ile sonuçlandırılacaktır. Şekil 12'de örnek olarak fonksiyon lojik motor listesi verilmiştir.

\begin{tabular}{|c|c|c|c|c|c|c|c|c|c|c|c|c|c|c|}
\hline & & & & \multicolumn{11}{|c|}{$\begin{array}{c}\text { Funktion Lojik (FL) } \\
\text { Motor Listesi }\end{array}$} \\
\hline & & & & \multicolumn{11}{|c|}{ Oğrenci Adr: lzzet ALAGOZ } \\
\hline & & & & \multicolumn{10}{|c|}{ Proje Adr: IZARES } & Revizyon:00 \\
\hline \multirow{2}{*}{ Cinaz Adh } & \multicolumn{3}{|c|}{ Oigeum Aratigs! } & \multicolumn{5}{|c|}{ SP(Switch Point) } & \multicolumn{2}{|c|}{ Alarm } & & \multirow{2}{*}{ Isim/ Fonksiyon } & \multicolumn{2}{|r|}{ Kontrol } \\
\hline & Birim & $4 m A$ & $20 \mathrm{~mA}$ & Limlt DeQ. & Fonksiyon & SP.Nr. & Alatif & Gecilene & Nr. & Oncelik & Grp. & & Sonuc & Tarihpparat \\
\hline YML3e. & & & & & & & & & & & & Sola OChnen Yän Motaru 3 & & \\
\hline & & & & & & & Her zantan & & & & & Gunvete Yok & & \\
\hline & & & & & & & $S P_{1}<Y S<S P 2$ & & & & & Dtomubese Calyna & & \\
\hline & & & & & & & Her zaman & & 93 & 1 & 1 & Motor Konums Alsmi & & \\
\hline & & & & & & & Her zanan & & 94 & 1 & 1 & Eleitrix Geriestome Alarmi & & \\
\hline & & & & & & & Her zanan & & 95 & 3 & 1 & Ozail Alarm & & \\
\hline
\end{tabular}

Şekil 12. Fonksiyon lojik motor listesi 


\subsubsection{Akış Diyagramları}

Fonksiyon lojik tanımlamaları yapılmış olan santral prosesinin akış diyagramlarının yapılması bir sonraki adım olarak görülmüştür. Programlanan tüm fonksiyonların akış diyagramları hazırlanmıştır. Örnek olarak, ölçüm cihazına ait akış diyagramı Şekil 13'de verilmiştir.

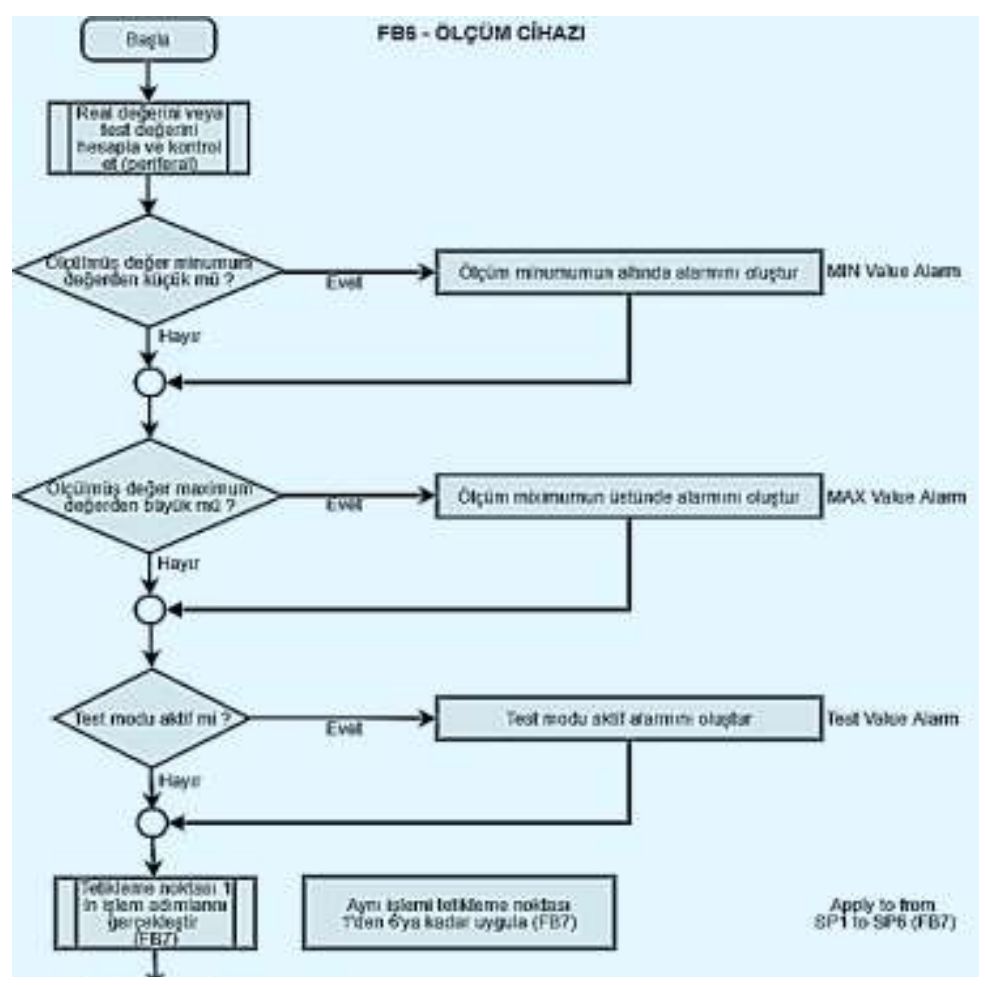

Şekil 13. Ölçüm cihazı akış diyagramı

\subsubsection{Fonksiyonlar ve Fonksiyon Blokları}

Program, fonksiyon bloklarına bölünerek yazılmıştır. Fonksiyonlar içerisinde program satır satır yazılarak fonksiyon blokları oluşturulmuş ve sistem yapı taşları hazırlanmıştır (Şekil 14). Doğrulama uygulamasına temel teşkil eden program parçacıkları işte bu fonksiyon bloklarıdır.
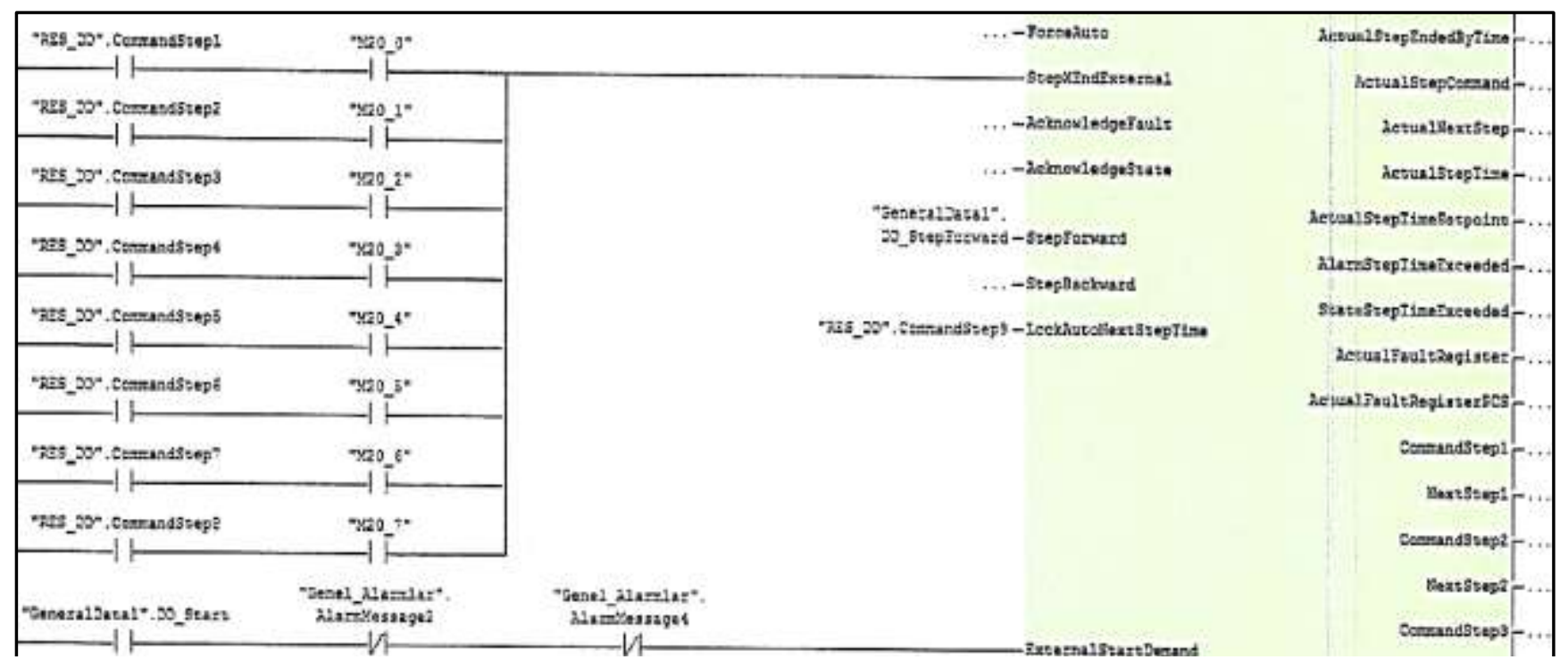

Şekil 14. Fonksiyonların yazılması 
Programlama dilinin alfa numerik yapısından dolayı sadece İngilizce karakterlere müsaade edildiğinden, programın yapı taşı niteliğindeki fonksiyon bloklarının içeriği ve pinler de İngilizce yazılmıştır. Oluşturulan fonksiyon blokları Tablo 2'de görülmektedir. Bloklar, data base adresleri ile çağrılarak kullanılmakta ve işlem bitimine kadar gerekli diğer fonksiyon blokları da çağrılarak çalıştırılmaktadır. Sırası veya süresi dolan fonksiyon bloğu tekrar ihtiyaç duyulduğunda merkezi işlem birimi tarafından çağrılmak üzere data base adresinde saklanmaktadır.

Tablo 2. Fonksiyon blokları

\begin{tabular}{ccccc}
\hline $\begin{array}{c}\text { Blok } \\
\text { Kodu }\end{array}$ & Blok Adı & $\begin{array}{c}\text { Programlama } \\
\text { Dili }\end{array}$ & $\begin{array}{c}\text { Data Base } \\
\text { Adresi }\end{array}$ & Blok Açılaması \\
\hline FB1 & Motor & S T L & 1750 & Fonksiyon Bloğu \\
FB2 & Gecikme Fonksiyonu & S T L & 328 & Fonksiyon Bloğu \\
FB3 & Alarm Mesaj1 & S T L & 380 & Fonksiyon Bloğu \\
FB4 & Gecikmeli Açılma & S T L & 172 & Fonksiyon Bloğu \\
FB5 & Ölçüm Cihazı & S T L & 3396 & Fonksiyon Bloğu \\
FB6 & Tetikleme Noktası & S T L & 592 & Fonksiyon Bloğu \\
FB7 & Analog Ç1kış & S T L & 646 & Fonksiyon Bloğu \\
FB8 & Motor İndeksi & S T L & 334 & Fonksiyon Bloğu \\
FB9 & Ölçüm Cihazı İndeksi & S T L & 1372 & Fonksiyon Bloğu \\
FB10 & Analog Çıkış İndeksi & S T L & 1412 & Fonksiyon Bloğu \\
FB11 & Kontrolör & S T L & 1492 & Fonksiyon Bloğu \\
FB12 & Dizi Denetleyici & S T L & 2350 & Fonksiyon Bloğu \\
FB13 & Aç1k Kapalı Zamanlayıc1 & S T L & 314 & Fonksiyon Bloğu \\
FB14 & Analog Giriş & S T L & 478 & Fonksiyon Bloğu \\
FB15 & Alarmlar & S T L & 1126 & Fonksiyon Bloğu \\
FB16 & PLC-HMI Kontrolör & S T L & 232 & Fonksiyon Bloğu \\
FB17 & Uzun Süreli Sayıcı & S T L & 176 & Fonksiyon Bloğu \\
FB18 & Servo Motor & S T L & 1750 & Fonksiyon Bloğu \\
FB19 & Oranlama & S T L & 242 & Fonksiyon Bloğu \\
FB97 & Common Supply & S T L & 3380 & Fonksiyon Bloğu \\
\hline & & &
\end{tabular}

\subsubsection{Motor Fonksiyon Bloğu}

Rüzgâr elektrik santrallerinde, servo motor dışında motorlarında kullanılabileceği ihtimali ile daha geniş bir perspektif elde edebilmek amacıyla, motor fonksiyonları için hazırlanmış algoritmaya göre, FB1 motor fonksiyon bloğu hazırlanmıştır (Şekil 15). Bu fonksiyon bloğu hazırlanırken, algoritmada belirtilen giriş-çıkış ve statik pinleri fonksiyon blok arayüzlerine girilmiştir. Sonrasında bu pinler arasında ilişkiyi kuracak mantık satırları, fonksiyon blok içindeki network mikro programlama ünitelerinde programlanmıştır. Artık bu motor fonksiyon bloğu rüzgâr türbinlerindeki her bir motor için kullanılmak üzere hazırdır. Sadece ayırt edici özellik katan data base numaraları atamaları ile de farklı motorlara ait programlama yeteneğine kavuşulmuştur. Motor fonksiyon bloğu üzerinde; programlama dili (STL), data base adresi (1750), versiyon numarası (2.2) ve bloğu oluşturanın imzası (IA) gibi bilgiler blok etiketinde yer almaktadır.

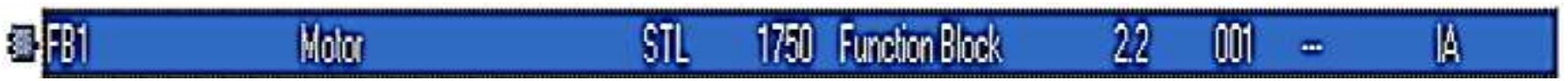

Şekil 15. FB1 motor fonksiyon bloğu 


\subsection{Ekran Görüntüleri}

Çalışmanın ihtiyacı karşılayan bir niteliği olması açısından, SCADA ekranları ile dokunmatik panel ekranlarının operatör tarafından kullanmasında kolaylık sağlayacak kullanım kılavuzu, Türkçe ve İngilizce olarak iki dilde hazırlanmıştır [23]. Örnek ekran görüntüleri ise Şekil 16, Şekil 17 ve Şekil 18 'de verilmiştir.

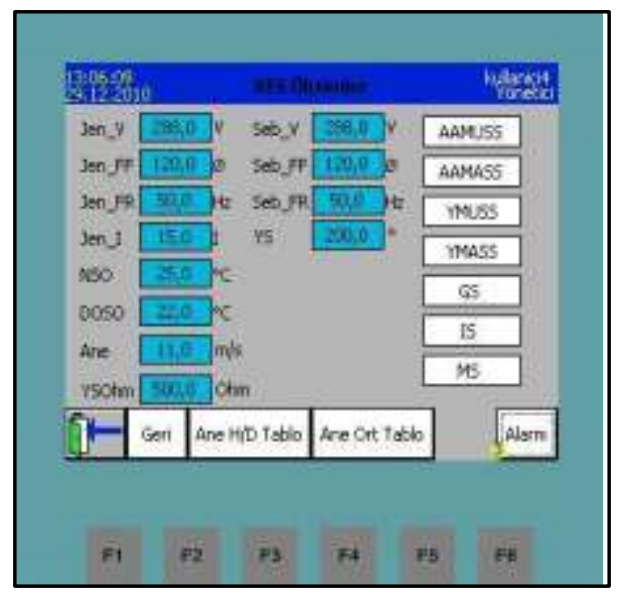

Şekil 16. Rüzgâr elektrik santrali ölçümleri ekran görüntüsü

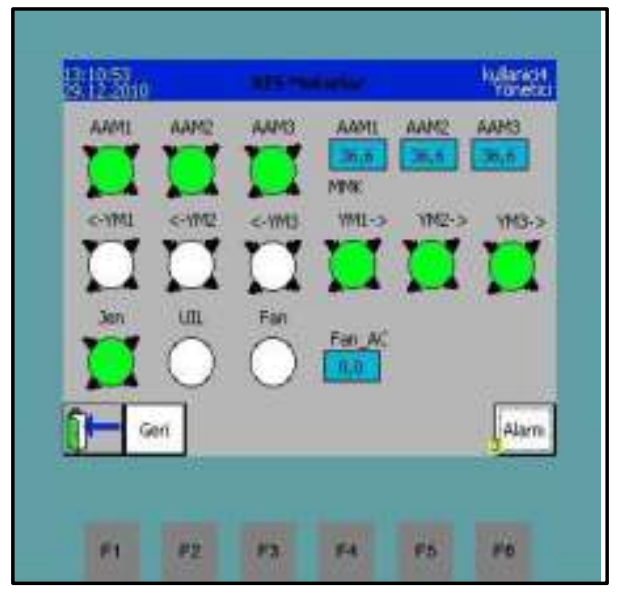

Şekil 17. Rüzgâr elektrik santrali motorları ekran görüntüsü

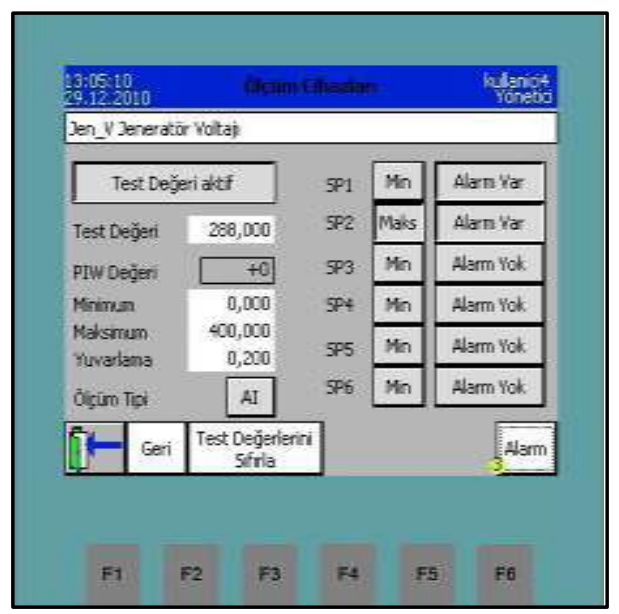

Şekil 18. Rüzgâr elektrik santrali sistem ölçüm cihazları ekran görüntüsü 


\subsection{Sistem İndeksleri}

Çalışmada, ekranda görüntülenebilecek bir indeks sistemi geliştirilerek tüm listenin bir sayfada düzenlenebilmesi sağlanmıştır. Şekil 19'da örnek olarak motorlara ait index verilmiştir. Sistemdeki tüm indeksler Türkçe ve İngilizce olarak iki dilde hazırlanmıştır.

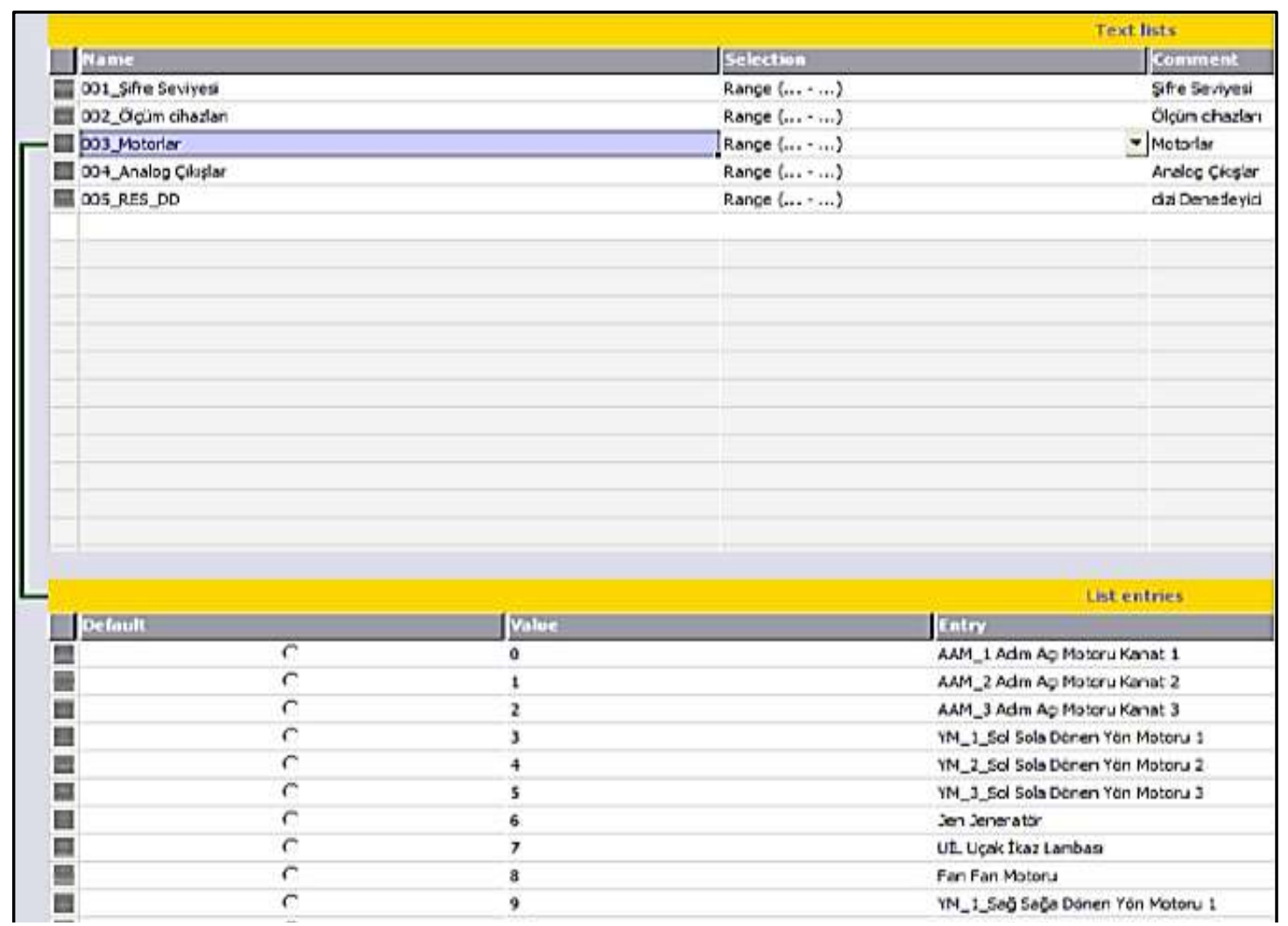

Şekil 19. Rüzgâr elektrik santrali motorlar indeksi

\subsection{Sistem Alarmları}

Alarm alındığında, operatör tarafından sorunun kolaylıkla anlaşılması için alarmlar Türkçe ve İngilizce olarak iki dilde yazılmıştır. Rüzgâr elektrik santralindeki tüm cihazların hata durumlarını önem derecesine göre gösteren öncelikli bir alarm sistemi oluşturulmuştur. Sadece bilgi vermek amaçlı gelen hataların alarm önceliği 3, daha önemli cihazların hatalarında alarm önceliği 2, en hayati hataların alarm önceliği ise 1'dir. Şekil 20'de örnek bir alarm tanımlaması verilmiştir.

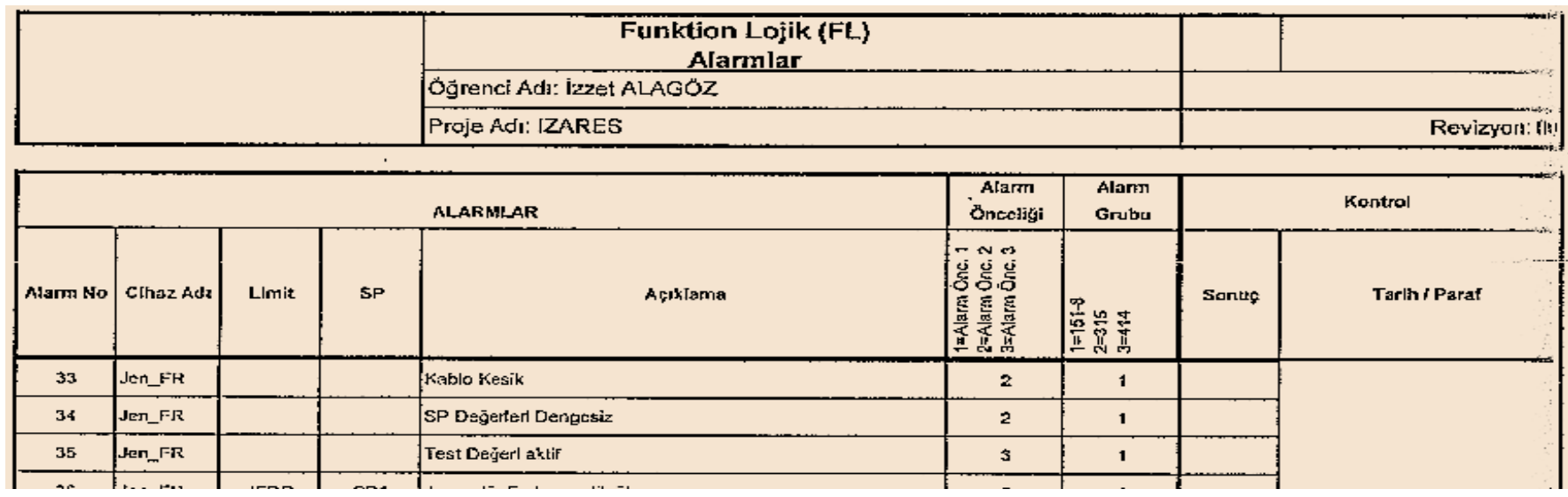

Şekil 20. Örnek bir alarm tanımlaması 


\subsection{Sistem Şifreleri ve Kullanım Seviyeleri}

Sistem şifre sorgulama ekranı Şekil 21'de görülmektedir. Sisteme ayrıca misafir, operatör, süpervizör ve bakım seviyelerinde de girişler olabileceğinden, şifre seviye düzenlemeleri de yapılmıştır.

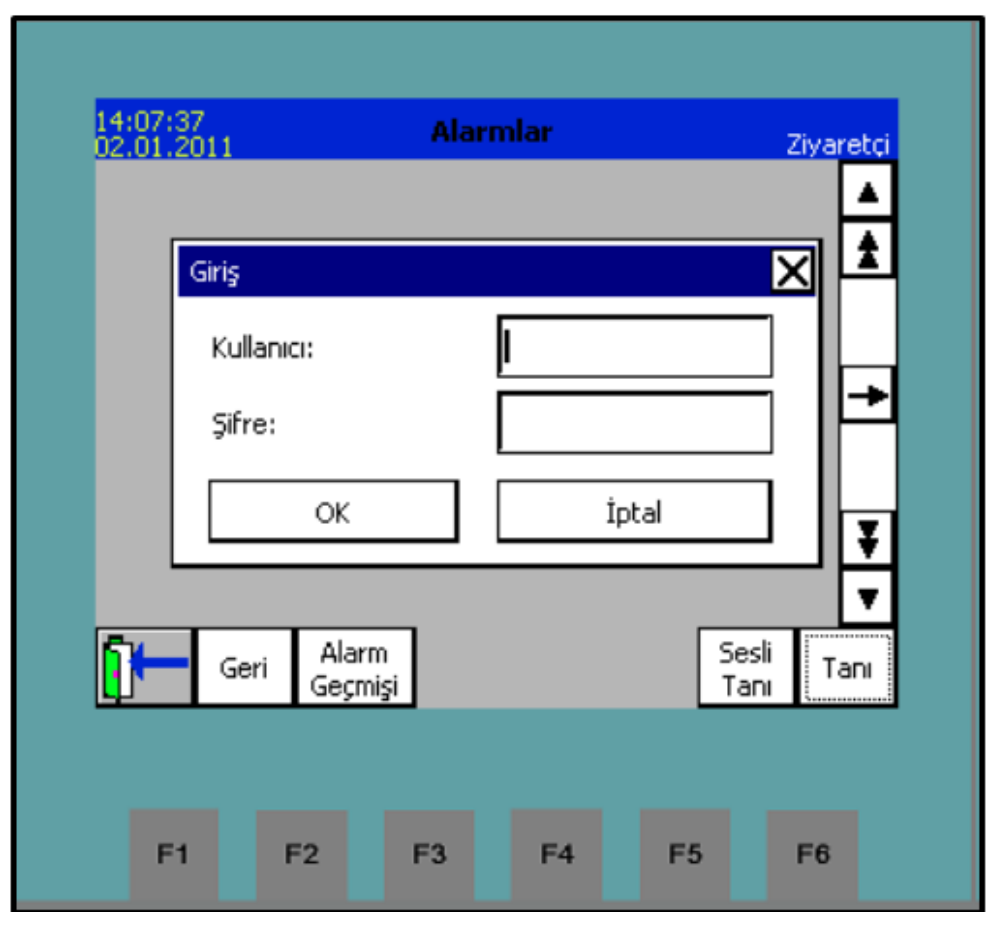

Şekil 21. Sistem şifreleri sorgulama ekranı

\section{Sistemin Çalışması}

Sistemde $0^{\circ}$ ile $70^{\circ}$ arasında döneceği kabul edilmiş, her biri bir kanadı yöneten üç adet adım açı motoru bulunmaktadır. Ancak bu değerler üretici firmalar tarafından belirlendiğinden, her bir santrale uygun olması için operatör tarafından değiştirilen ve hafizada kaydedilen bir sistem geliştirilmiştir. Anemometrenin alt sınır değeri olan $4 \mathrm{~m} / \mathrm{s}$ 'nin altında ve üst sınır değeri olan 25 $\mathrm{m} / \mathrm{s}$ 'nin üstünde santral durdurulmaktadır. Anemometre $4 \mathrm{~m} / \mathrm{s}$ ölçtüğünde adım açı motoru $0^{\circ}, 25$ $\mathrm{m} / \mathrm{s}$ ölçtüğünde ise $70^{\circ}$ dir. Adım açı motorunun hareket açısını belirleyen bir ortalama değer sistemi mevcuttur. Son 3 dakika içerisinde her 2 saniyede bir değer ölçülerek toplam 90 değerin ortalaması alınır ve ortalaması alınan açı değerlerinin karşılığı olan analog çıkış ile adım açı motoru istenilen seviyeye getirilir. Örnek üzerinde açıklarsak; 0 . saniye ile 180. saniye arasında anemometre ortalama $15 \mathrm{~m} / \mathrm{s}$ hızla dönmüştür. Bu alınan 90 değerin ortalamasıdır. Ardından üretici firmanın belirlediği $15 \mathrm{~m} / \mathrm{s}$ hızla dönmeye karşılık gelen $35^{\circ}$ değeri elde edilmiştir. $35^{\circ}$ ye karşılık olarak \%50'lik bir çalışmayla motor istenen noktaya getirilmiştir. 180. ve 360. saniyeler arasında devamlı $35^{\circ}$ bir açı ile durmaktadır. Bu sırada anemometre yeni ortalama değerini elde etmektedir. $\mathrm{Bu}$ elde edilen yeni değer ile de 360. ve 480. saniyeler arasında bulunacaktır. Sistem bu şekilde çalışmasına devam etmektedir. Diğer önemli bir konu ise yön motorudur. Programda 6 tane yön motoru varmış gibi görünse de aslında üç adet yön motoru bulunmaktadır. İkinci ve üçüncü motorlar birinciye paralel olarak tasarlanmıştır. Sol ve sağ diye ayrılan yön motorlarının ayrılma sebebi ise dönme yönüdür. Yön sensöründen rüzgâr yönü ile ilgili $0^{\circ}$ ile $180^{\circ}$ arasında bir değer gelirse o zaman sol isimli yön motorları hareket edecektir. Ancak $180^{\circ}$ ile $360^{\circ}$ arasında bir değer elde edilirse o zaman sağ isimli motorlar hareket edecektir. Aslında motor, geliştirilen programda sağ ve sol olmak üzere ikiye ayrılmıştır. Gerçekte bu 2 adet fonksiyon bloğunu ve 1 adet gerçek 
motoru temsil etmektedir. Dolayısıyla 3 adet yön motoru için 6 adet fonksiyon bloğu bulunmaktadir.

\section{Bulgular ve Tartışma}

$\mathrm{Bu}$ çalışmada geliştirilen kod kütüphanesinde, her santral projesinde kullanılması zorunlu olan açı ve yön kontrol sistemi, eşleme, meteorolojik sensör ve buna benzer uygulamaların yanı sıra herhangi bir endüstriyel proses uygulamasında da kullanılabilecek motor kontrol, motor index, ölçüm cihazı, analog giriş/çıkış ve alarm gibi fonksiyonlar da bloklar halinde tanımlanmıştır. Kod kütüphanesinin oluşturulmasından sonra donanım ve yazılım parametreleri de esas alınarak programlama çalışmaları yapılmıştır. Sistemin kendi yazılım diline ve birçok haberleşme protokolüne uyumlu olan bir PLC programından sonra da SCADA yazılımı oluşturulmuştur. Oluşturulan kod kütüphanesinin tarif edildiği şekilde çalışıp çalışmadığının denetlemesi için doğrulama uygulamasının akademik yeterlilikte bir ekip ile birlikte yapılması ve onaylanması programının güvenilirliğinin kanıtı olması açısından gerekli görülmüştür. Kullanılan donanımın ve geliştirilen programın testi, gerçek kontrolör ve panel üzerinde uygulanmış ve yapılabilirliği kanıtlanmıştır. Geliştirilen program farklı türbinlere uygulanırken, devreye alınması çalışmalarından önce doğal olarak birtakım revizyonların gerçekleştirilmesine ihtiyaç duyulabilir.

\section{Sonuçlar}

$\mathrm{Bu}$ çalışmada, açık bir sistem olarak geliştirilen IZARES adlı sistem ile rüzgâr elektrik santrali projelerinde kullanılabilecek ve diğer kontrol programlarına da temel olabilecek bir fonksiyon kod kütüphanesi geliştirilmiş olup türbin üreticilerinin ve yatırımcılarının kontrol sistemleri konusundaki marka bağımlılıklarının önüne geçilerek her marka işlemci ile kontrol programlaması yapabilmenin temelleri belirli bir standarda oturtulmaya çalışılmıştır. Bu sayede rüzgâr elektrik santrali kontrol sistemlerinde standardizasyonun sağlanmasına katkı sağlanmış ve türbin üreticilerinin başka alanlara yoğunlaşmalarının önü açılmıştır. İhtiyaçların çeşitliliğine bağlı olarak da geliştirilebilir özellikte olan bu sistem, hem bundan sonraki çalışmalara öncü olabilecek özellikte, hem de Türkiye ve dünyadaki sanayiciler için incelenebilecek niteliktedir. Bundan sonraki adım ise; küçük ve orta ölçekli (1000 kW ve daha küçük) rüzgâr türbini için geliştirilmiş olan bu sistemin, daha büyük güçteki türbinler ve rüzgâr tarlaları için de genişletilerek geliştirilmesi olacaktır.

\section{Teşekkür}

Doğrulama denetimlerindeki katkılarından dolayı Ege Üniversitesi Elektrik Elektronik Mühendisliği Bölümüne, Christ Goema GmbH Türkiye Koordinatörü Sayın Konstantinos Kaleadis'e ve donanım desteği için ABT Endüstri Enerji Sistemleri San.Tic. ve A.Ş. Genel Müdürü Sayın Murat Alagöz'e teşekkürlerimi sunarım.

\section{Yazar Katkıları}

İA çalışmayı yapmış ve makaleyi hazırlamıştır, makalenin son halini onaylamıştır.

\section{Çıkar Çatışması}

Yazarlar, rakip çıkarları olmadıklarını beyan etmektedirler. 


\section{Kaynaklar}

[1]. Alagöz İ., "Rüzgâr Elektrik Santrallerinin Kontrolü için Kullanılabilecek Validasyonlu Kod Kütüphanesi Geliştirilmesi”, Doktora Tezi, Ege Üniversitesi, Fen Bilimleri Enstitüsü, 2011.

[2]. Ülgen K., "Güneş Santralları", Ders Notları, İzmir, 2007.

[3]. Çetin N.S., "Rüzgar Türbinleri Güvenli Çalışma Modelleri”, Ders Notları, İzmir, 2008.

[4]. Kısar A.O., "Rüzgardan Enerji Üretimi ve Rüzgar Türbinlerinin Evrimi”, EMO İstanbul Şube Bülteni, İstanbul, 2009.

[5]. Sülün M., "Rüzgar Enerjisi”, Bitirme Projesi, Dokuz Eylül Üniversitesi, İzmir, 2007.

[6]. Gül İ., Kolip A., "Parça Kanatlı Savonius Rüzgâr Türbin Performansının İncelenmesi”, ElCezerî Fen ve Mühendislik Dergisi, 2018, 5(3): 816-827.

[7]. Tanrı̈ven M., "Rüzgâr ve Güneş Enerjili Güç Sistemleri”, Ders Notları, İstanbul, 2009.

[8]. Yüksel Y.E., Öztürk M., "Evsel Uygulamalar için Birleşik Rüzgar-Güneş-Hidrojen Sisteminin Termodinamik Analizi”, El-Cezerî Fen ve Mühendislik Dergisi, 2016, 3(3): 401416.

[9]. Duellmann R., "EIC Workshop", Wind Turbine Technology, Nordex Company Technical Publications, England, 2010.

[10]. Enercon Gmbh, "Enercon Magazine for Wind Energy”, Germany, 2009.

[11]. NI Engineer Ambitiousl, https://www.ni.com/en-tr/innovations/white-papers/08/wind-turbinecontrol-methods.html, Erişim Tarihi: 30.04.2019.

[12]. IEC 61131, "Programlanabilir Mantık Denetleyiciler (PLC)", 1993.

[13]. Ackermann T., "Wind Power in Power Systems", EMO Yayınları, Ankara, 2009.

[14]. Wikipedia, https://en.wikipedia.org/wiki/Good_automated_manufacturing_practice, Erişim Tarihi:10.05.2019.

[15]. Arifoğlu B., Beşer E., “Otomasyon Sistemleri Ders Notları”, Kocaeli, 2015.

[16]. Bodur A., "Pratik Dağıtılmış Kontrol Sistemleri”, Bileşim Yayınları, İstanbul, 2006.

[17]. Alc1 M., "PLC Programlama Esasları", Ders Notları, İzmir, 2008.

[18]. Yağımlı M., Akar F., "Programlanabilir Lojik Denetleyiciler”, Beta Yayınları, İstanbul, 2008.

[19]. Ataseven M.S., Ataseven S., "Senkron Rüzgar Türbinleri ve Kontrol Sistemleri”, EMO 4. Otomasyon Sempozyumu, Samsun, 2007.

[20]. Suss T., "An Introductory to PLC Programing Blocks", Goema Technological Seminars, Stuttgart, 2006.

[21]. Linemann S., "Low Level SCADAs", Siemens Seminars, Holland, 2002.

[22]. Bolton W., "Mekatronik - Makine ve Elektrik Mühendisliğinde Elektronik Kontrol Sistemleri", Dahi Yayınları, İstanbul, 2009.

[23]. Panel KTP-600 Türkçe Kullanım Kılavuzu, https://yadi.sk/i/McHzUMSNnrigXQ, Erişim Tarihi:10.01.2020. 